\title{
Optimization of a Validated UV-Spectrophotometric Methodology for Assessment of Apigenin in Bulk Powder
}

\author{
Priya Shetti ${ }^{1}$, Sunil S. Jalalpure ${ }^{2, *}$ \\ ${ }^{1}$ Dr. Prabhakar Kore Basic Science Research Center, KLE Academy of Higher Education and Research, Nehru Nagar, Belagavi, \\ Karnataka, INDIA. \\ ${ }^{2}$ Department of Pharmacognosy, KLE College of Pharmacy Belagavi, KLE Academy of Higher Education and Research, Nehru Nagar, \\ Belagavi, Karnataka, INDIA.
}

\begin{abstract}
Introduction: Apigenin (4,5,7 Trihydroxyflavone) is a natural compound of flavonoids class, which is found in various plant constituents. Since primitive years, Apigenin has been used as a traditional medicine, because it possesses biological functions. Common ayurvedic formulations comprising apigenin are in market. Hence quality control of preparation covering apigenin is desirable. Objectives: In present study, pointed to enhance and validate UV Spectrophotometric method to evaluation of apigenin in bulk powder. Methods: Using methanol as solvent, UV Spectrophotometric method was developed. Apigenin showed supreme absorbance wavelength at $267 \mathrm{~nm}$. New technique enhanced and validated in terms parameters such Specificity, Discrimination, Linearity, Correctness, Ruggedness, Solution stability as per each ICH guidelines. Results: The detector response for apigenin was linear in the sure concentration range of $2 \mu \mathrm{g} / \mathrm{mL}$ $10 \mu \mathrm{g} / \mathrm{mL}$ with correlation coefficient of 0.9995 . Newly developed method was found to be specific, Selective linear, Precise, Rugged, reproducible for estimation of apigenin with \%RSD values less than $2 \%$. Conclusion: In this study Development and Validation of UV-Spectrophotometric method can be employed for the apigenin assessment in bulk powder.
\end{abstract}

Key words: Apigenin, Absorbance, ICH guidelines, Ruggedness, Spectrophotometric, Ayurvedic Formulations.

\section{INTRODUCTION}

Apigenin is a very significant natural compound existing in various fruits and vegetables such as parsley, celeriac, celery, chamomile tea, orange, apple, tomatoes. ${ }^{1}$ Apigenin in Figure 1 is a flavonoid that is used as a traditional medicine for decades, as it establish to show DPPH, antioxidant, in vivo animal anti-inflammatory, cytotoxic study, anti-bacterial, anti-viral and numerous biological activities. One of the very significant activities of apigenin is anticancer activity. ${ }^{24}$ Numerous ayurvedic formulations comprising apigenin were marketed for health care delivery systems. ${ }^{5}$ The quality control of formulations containing apigenin is important in the ayurvedic industries. Literature survey revealed that analytical methods such as spectrophotometric, HPLC and HPTLC methods $s^{6-9}$ were reported for the estimation of apigenin in various plant extracts. The stated methods were having their own confines such as extra time consuming, use of costly and hazardous solvents. As per the literature review, there was no established UV spectrophotometric method for valuation of apigenin in the form of pure form. Henceforth, it is needed to develop and validate UV spectrophotometric method estimation of apigenin by using newer solvent system. In the present research an effort has been made to develop
Submission Date: 26-02-2021; Revision Date: 06-05-2021; Accepted Date: 29-07-2021

DOI: 10.5530/ijper.56.1.33 Correspondence: Dr. Sunil S Jalalpure, Professor,Department of Pharmacognosy, KLE College of Pharmacy Belagavi, KLE University, Belagavi-590010, Karnataka,INDIA

E-mail: jalalpuresunil@ rediffmail.com

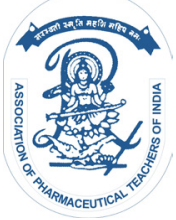

www.ijper.org 


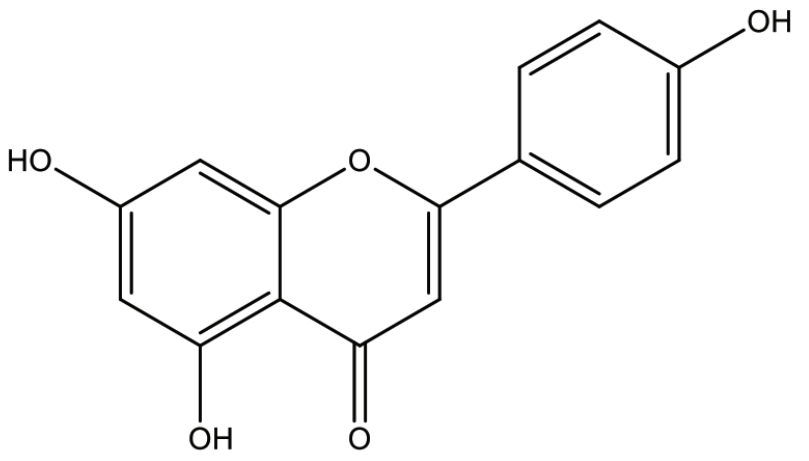

5,7-dihydroxy-2-(4-hydroxyphenyl)-4H-chromen-4-one

Figure 1: 2D structure of Apigenin.

and validate new UV-spectrophotometric method for estimation of apigenin in bulk powder.

\section{MATERIALS AND METHODS}

\section{Chemicals}

Apigenin was achieved as gift sample from Aktin chemicals, China. Beneficial chemicals and reagents used for the analysis pure, high analytical grade gotten from KAHER'S Dr. Prabhakar Kore Basic Science Research Center, Belagavi. UV-Spectrophotometer of Shimadzu make and model UV-1900 having UV probe software were used for analysis. Calibrated weighing balance was used for weighing drug sample in the study.

\section{Method Optimization}

Development also optimization of new UV Spectrophotometric method was accepted by selecting the proper solvent system the wavelength were recognized from review literature. Solubility of apigenin was screened by taking various solvents ethanol, methanol. In order to select the solvent system few trials were carried out, finally methanol was chosen as a solvent. Primary and secondary stock solution of apigenin was prepared by dissolving it in methanol. From these solutions working standard solution containing $10 \mu \mathrm{g} / \mathrm{mL}$ of apigenin was scanned between the wavelength regions of 400 - $200 \mathrm{~nm}$ against methanol as blank. The UV spectra were shown in and absorption curve showed characteristic absorption maxima at $267 \mathrm{~nm}$ and it was selected for analysis of apigenin. ${ }^{10,11}$

\section{Method Validation}

In order to validate newly developed method parameters as per the ICH guidelines (ICH guidance Q2A; Q2B) was followed. ${ }^{12-15}$

\section{Specificity and selectivity}

Employed standard solution containing $2 \mu \mathrm{g} / \mathrm{mL}$ Apigenin was observed between the range of 400-200nm. Spectrum of solvent as blank was obtained, analyzed for any interference of solvent at maximum wavelength of absorbance.

\section{Linearity and range}

While execution the study for linearity, $10 \mathrm{mg}$ of apigenin weighed and transferred into $10 \mathrm{ml}$ of volumetric flask and volume was attuned to the mark using methanol to obtained $1000 \mu \mathrm{g} / \mathrm{mL}$ solution of apigenin. From this standard stock the working stock was prepared which consist of $1 \mathrm{ml}$ of standard stock was taken placed in another $10 \mathrm{~mL}$ volumetric flask covering methanol solvent and the volume was made up to the mark to $10 \mathrm{~mL}$, later further serial dilutions were made to prepare 2, 4, 6, 8 and $10 \mu \mathrm{g} / \mathrm{mL}$ solutions of apigenin. Solutions were ready in triplicates and absorbance's was measured at $267 \mathrm{~nm}$.

\section{Limit of Detection and Limit of Quantification}

LOD and LOQ was calculated by using statistical calculations using formulas:

$\mathrm{LOD}=3.3 \times \mathrm{SD}$ of $\mathrm{y}$-intercept/ Slope of the calibration curve and $\mathrm{LOQ}=10 \mathrm{x}$ SD of $\mathrm{y}$ - intercept/ Slope of the calibration curve.

$\mathrm{LOD}=3.3 \times$ standard deviation of regression/ Slope

LOQ $=10 \times$ standard deviation of regression/ Slope

\section{Precision}

Precision was measured in six replicates of solution containing apigenin that was prepared and the absorbancewas recorded at $267 \mathrm{~nm}$ on sameday at different time intervals. On altered days the obtained system precision, intraday precision and interday precision data and absorbance were measured and \% RSD was calculated.

\section{Ruggedness and Reproducibility}

In determine the ruggedness normally six replicates of solutions containing apigenin were prepared and absorbance of each replicate was measured by different analyst also by using different instruments and \%RSD as calculated for absorbance.

\section{Solution and standard stock solution stability}

In order to check solution stability and obtained stability, fresh stock was prepared and dilutions were made using fresh solvent, absorbance's of each dilutions containing 
apigenin was compared with that of old stock dilutions and $\%$ RSD for absorbance's was calculated.

\section{RESULTS AND DISCUSSION}

\section{Optimization and validation}

Solvent development step involves the use of methanol in which apigenin showed spectrum with maximum absorbance at $267 \mathrm{~nm}$. Developed method parameters were presented below.

\section{Specificity and selectivity}

By obtaining solvent spectrum there was no interference of absorbance at $267 \mathrm{~nm}$ hitch highlighted the specificity and method selectivity. The UV spectrum of solvent and apigenin is represented in Figure 2 and Figure 3 respectively.

\section{Linearity and Range}

Linearity and range was resolute by plotting standard calibration curve using concentration UV absorbance's obtained by linear dilution of apigenin. The absorbance range was between the concentration of 2, 4, 6, 8 and $10 \mu \mathrm{g} / \mathrm{mL}$. The regression equation of apigenin was 0.999 . Linearity data as signified in Table 1 . Overlay spectrum of linearity of apigenin is shown in Figure 4 with standard calibration curve was presented in Figure 5.

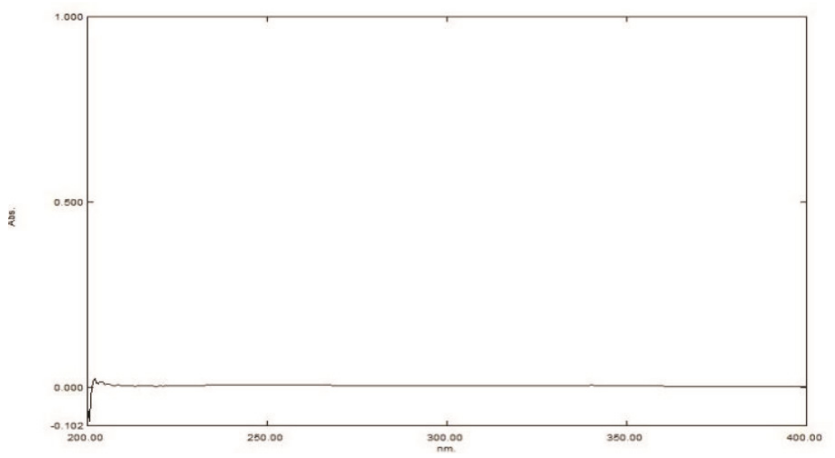

Figure 2: UV-Spectrum of Methanol.

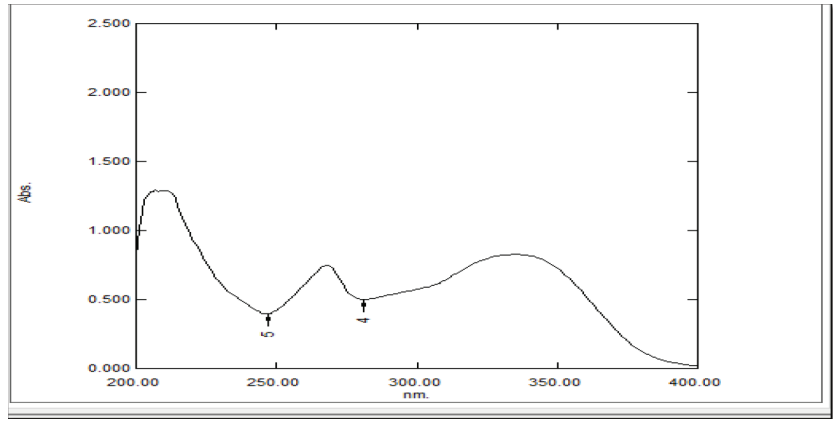

Figure 3: UV-Spectrum of Apigenin.

\section{Table 1: Linearity and range data of apigenin.}

\begin{tabular}{|c|c|c|}
\hline Sr. No & Concentration & Absorbance at $\mathbf{2 6 7 n m}$ \\
\hline $\mathbf{1}$ & $2 \mu \mathrm{g} / \mathrm{mL}$ & 0.179 \\
\hline $\mathbf{2}$ & $4 \mu \mathrm{g} / \mathrm{mL}$ & 0.288 \\
\hline $\mathbf{3}$ & $6 \mu \mathrm{g} / \mathrm{mL}$ & 0.401 \\
\hline $\mathbf{4}$ & $8 \mu \mathrm{g} / \mathrm{mL}$ & 0.519 \\
\hline $\mathbf{5}$ & $10 \mu \mathrm{g} / \mathrm{mL}$ & 0.641 \\
\hline $\mathbf{r}^{2}$ & & 0.999 \\
\hline Slope & & 0.05775 \\
\hline LOD & & $0.27 \mu \mathrm{g} / \mathrm{mL}$ \\
\hline LOQ & & $0.83 \mu \mathrm{g} / \mathrm{Ml}$ \\
\hline
\end{tabular}

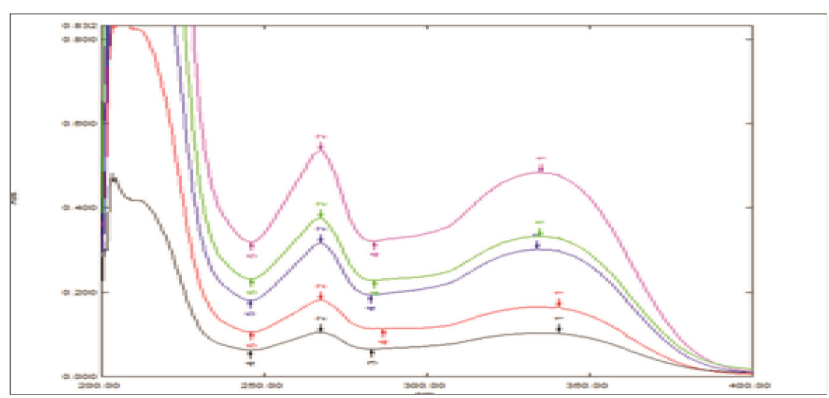

Figure 4: Overlay spectrum of Apigenin.

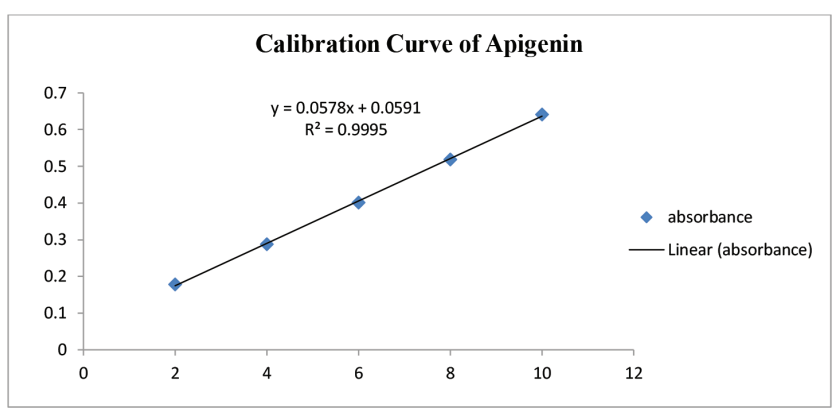

Figure 5: Standard calibration plot of Apigenin.

\section{Limit of Detection and Limit of Quantification}

By statistical calculation LOD and LOQ was found to be $0.27 \mu \mathrm{g} / \mathrm{mL}$ and $0.83 \mu \mathrm{g} / \mathrm{ml}$ respectively.

\section{Precision}

Method was found to be precise as the \%RSD calculated for six replicates solution of apigenin at each precision level was found to be less than 2\% (Table 2).

\section{Ruggedness and Reproducibility}

The $\%$ RSD values calculated for apigenin was found to be less than $2 \%$ which indicates that the method was robust with slight change in the $\%$ composition of solvent system and reproducible as \%RSD obtained for 


\begin{tabular}{|c|c|c|c|c|c|c|}
\hline Precision & $\begin{array}{l}\text { System } \\
\text { precision }\end{array}$ & $\begin{array}{c}\text { Intraday } \\
1^{\text {st }} \mathrm{hr}\end{array}$ & Intraday $5^{\text {th }} \mathrm{hr}$ & $\begin{array}{c}\text { Interday } \\
-1 \text { Precision }\end{array}$ & $\begin{array}{c}\text { Interday } \\
-2 \text { Precision }\end{array}$ & $\begin{array}{c}\text { Interday } \\
-3 \text { Precision }\end{array}$ \\
\hline $2 \mu \mathrm{g} / \mathrm{mL}$ & 0.164 & 0.171 & 0.168 & 0.171 & 0.155 & 0.161 \\
\hline $2 \mu \mathrm{g} / \mathrm{mL}$ & 0.167 & 0.174 & 0.172 & 0.174 & 0.159 & 0.165 \\
\hline $2 \mu \mathrm{g} / \mathrm{mL}$ & 0.168 & 0.172 & 0.172 & 0.172 & 0.154 & 0.169 \\
\hline $2 \mu \mathrm{g} / \mathrm{mL}$ & 0.166 & 0.167 & 0.174 & 0.167 & 0.157 & 0.167 \\
\hline $2 \mu \mathrm{g} / \mathrm{mL}$ & 0.167 & 0.164 & 0.176 & 0.164 & 0.159 & 0.164 \\
\hline $2 \mu \mathrm{g} / \mathrm{mL}$ & 0.166 & 0.166 & 0.177 & 0.166 & 0.161 & 0.166 \\
\hline$\%$ RSD & $0.82 \%$ & $0.90 \%$ & $1.87 \%$ & $0.90 \%$ & $1.69 \%$ & $1.65 \%$ \\
\hline $6 \mu \mathrm{g} / \mathrm{mL}$ & 0.396 & 0.357 & 0.407 & 0.357 & 0.382 & 0.382 \\
\hline $6 \mu \mathrm{g} / \mathrm{mL}$ & 0.4 & 0.363 & 0.407 & 0.363 & 0.382 & 0.383 \\
\hline $6 \mu \mathrm{g} / \mathrm{mL}$ & 0.4 & 0.365 & 0.408 & 0.365 & 0.383 & 0.382 \\
\hline $6 \mu \mathrm{g} / \mathrm{mL}$ & 0.407 & 0.365 & 0.409 & 0.362 & 0.39 & 0.389 \\
\hline $6 \mu \mathrm{g} / \mathrm{mL}$ & 0.408 & 0.362 & 0.41 & 0.369 & 0.392 & 0.39 \\
\hline $6 \mu \mathrm{g} / \mathrm{mL}$ & 0.409 & 0.363 & 0.412 & 0.365 & 0.389 & 0.39 \\
\hline$\%$ RSD & $1.32 \%$ & $0.81 \%$ & $0.47 \%$ & $0.81 \%$ & $1.16 \%$ & $1.04 \%$ \\
\hline $10 \mu \mathrm{g} / \mathrm{mL}$ & 0.633 & 0.591 & 0.639 & 0.633 & 0.631 & 0.619 \\
\hline $10 \mu \mathrm{g} / \mathrm{mL}$ & 0.634 & 0.597 & 0.641 & 0.634 & 0.636 & 0.622 \\
\hline $10 \mu \mathrm{g} / \mathrm{mL}$ & 0.639 & 0.594 & 0.64 & 0.639 & 0.634 & 0.62 \\
\hline $10 \mu \mathrm{g} / \mathrm{mL}$ & 0.64 & 0.589 & 0.641 & 0.64 & 0.637 & 0.622 \\
\hline $10 \mu \mathrm{g} / \mathrm{mL}$ & 0.641 & 0.591 & 0.642 & 0.641 & 0.64 & 0.623 \\
\hline $10 \mu \mathrm{g} / \mathrm{mL}$ & 0.641 & 0.595 & 0.643 & 0.641 & 0.641 & 0.624 \\
\hline \%RSD & $0.56 \%$ & $0.50 \%$ & $0.22 \%$ & $0.56 \%$ & $0.58 \%$ & $0.29 \%$ \\
\hline
\end{tabular}

\begin{tabular}{|c|c|c|c|c|c|}
\hline ن̊ & 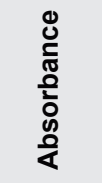 & ن̊ & 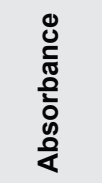 & ঠ் & 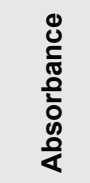 \\
\hline $2 \mu \mathrm{g} / \mathrm{mL}$ & 0.168 & $6 \mu \mathrm{g} / \mathrm{mL}$ & 0.368 & $10 \mu \mathrm{g} / \mathrm{mL}$ & 0.633 \\
\hline $2 \mu \mathrm{g} / \mathrm{mL}$ & 0.172 & $6 \mu \mathrm{g} / \mathrm{mL}$ & 0.369 & $10 \mu \mathrm{g} / \mathrm{mL}$ & 0.639 \\
\hline $2 \mu \mathrm{g} / \mathrm{mL}$ & 0.172 & $6 \mu \mathrm{g} / \mathrm{mL}$ & 0.369 & $10 \mu \mathrm{g} / \mathrm{mL}$ & 0.64 \\
\hline $2 \mu \mathrm{g} / \mathrm{mL}$ & 0.174 & $6 \mu \mathrm{g} / \mathrm{mL}$ & 0.362 & $10 \mu \mathrm{g} / \mathrm{mL}$ & 0.641 \\
\hline $2 \mu \mathrm{g} / \mathrm{mL}$ & 0.177 & $6 \mu \mathrm{g} / \mathrm{mL}$ & 0.363 & $10 \mu \mathrm{g} / \mathrm{mL}$ & 0.641 \\
\hline $2 \mu \mathrm{g} / \mathrm{mL}$ & 0.176 & $6 \mu \mathrm{g} / \mathrm{mL}$ & 0.365 & $10 \mu \mathrm{g} / \mathrm{mL}$ & 0.642 \\
\hline \%RSD & $1.87 \%$ & $\%$ RSD & $0.84 \%$ & $\%$ RSD & $0.51 \%$ \\
\hline
\end{tabular}

absorbance's of each replicate of solutions was within the acceptance by change in the analyst and instrument (Table 3).

\section{Solution stability}

The solution stability for apigenin was determined by the $\%$ RSD or absorbance was calculated from prepared fresh solution and old solution containing apigenin. Results analyzed were found to be within the acceptance and data obtained revealed the standard stock solution.

\begin{tabular}{|c|c|c|c|}
\hline \multicolumn{4}{|c|}{ Table 4: Solution stability data of apigenin. } \\
\hline \multicolumn{2}{|c|}{ Solution stability } & $\begin{array}{c}\text { Fresh stock } \\
\text { dilutions }\end{array}$ & $\begin{array}{c}\text { Old stock } \\
\text { dilutions }\end{array}$ \\
\hline Replicates & Conc. & Apigenin & Apigenin \\
\hline $\mathbf{1}$ & $2 \mu \mathrm{g} / \mathrm{mL}$ & 0.168 & 0.179 \\
\hline $\mathbf{2}$ & $2 \mu \mathrm{g} / \mathrm{mL}$ & 0.172 & 0.167 \\
\hline $\mathbf{3}$ & $2 \mu \mathrm{g} / \mathrm{mL}$ & 0.172 & 0.172 \\
\hline $\mathbf{4}$ & $2 \mu \mathrm{g} / \mathrm{mL}$ & 0.174 & 0.172 \\
\hline $\mathbf{5}$ & $2 \mu \mathrm{g} / \mathrm{mL}$ & 0.177 & 0.171 \\
\hline $\mathbf{6}$ & $2 \mu \mathrm{g} / \mathrm{mL}$ & 0.176 & 0.169 \\
\hline \multicolumn{2}{|c|}{$\% \mathrm{RSD}$} & $1.87 \%$ & $1.17 \%$ \\
\hline
\end{tabular}

Solution stability study was done for 4 days and data have been displayed in (Table 4).

\section{CONCLUSION}

This paper presents in detail the development of a portable low-cost UV spectrophotometer which, by using an isolated compound, allows detection of developed, validated parameters, providing effective accurate results. Hence, the developed method is accurate, precise, reproducible and used as a quality control tool for analysis of apigenin in bulk. In future the methods 
desirable to apply for estimation of apigenin in its various extract and other marketed dosage forms.

\section{ACKNOWLEDGEMENT}

The authors are thankful to KAHER's Dr. Prabhakar Kore's BSRC Belagavi for providing necessary facility to carry out present research work. Authors are also thankful to Aktin Chemicals, China for providing Apigenin as a gift sample.

\section{CONFLICT OF INTEREST}

The authors declare no conflict of interest.

\section{ABBREVIATIONS}

$\mu \mathrm{g}:$ Microgram; mL: Milliliter; LOD: Limit of Detection; LOQ: Limit of Quantification; UV: Ultra violet spectrophotometer; RSD: Relative Standard Deviation; ICH: International Council of Harmonization.

\section{Author Contribution}

All the authors have equally contributed for the development and validation of apigenin. Ms. Priya Shetti contributed to develop and validate and method for apigenin in its pure form. Dr. Sunil S. Jalalpure guided for the present research work also in the reviving literature and writing the paper work.

\section{REFERENCES}

1. Salmani JMM, Zhang XP, Jacob JA, Chen BA. Apigenin's anticancer properties and molecular mechanisms of action: recent advances and future prospectives. Chin J Nat Med. 2017 May 1;15(5):321-9. doi: 10.1016/S18755364(17)30052-3, PMID 28558867

2. Yan X, Qi M, Li P, Zhan Y, Shao H. Apigenin in cancer therapy: anti-cancer effects and mechanisms of action. Cell Biosci. 2017 Dec;7(1):50. doi: 10.1186/s13578-017-0179-x, PMID 29034071
3. Zhang J, Huang Y, Liu D, Gao Y, Qian S. Preparation of apigenin nanocrystals using supercritical antisolvent process for dissolution and bioavailability enhancement. Eur J Pharm Sci. 2013 Mar 12;48(4-5):740-7. doi: 10.1016/j. ejps.2012.12.026, PMID 23305994.

4. Cvetanović A, Švarc-Gajić J, Gašić U, Tešić Ž, Zengin G, Zeković Z, Đurović $S$. Isolation of apigenin from subcritical water extracts: optimization of the process. J Supercrit Fluids. 2017 Feb 1;120:32-42. doi: 10.1016/j. supflu.2016.10.012.

5. Das C, Ghosh G, Bose A, Das D. Analytical methods for standardization of ayurvedic asavas and aristas; A review. pharmaceutical-sciences. 2019 May 27;81(3):396-405. doi: 10.36468/pharmaceutical-sciences.523.

6. Attarde DL, Pal SC, Bhambar RS. Validation and development of HPTLC method for simultaneous estimation of apigenin and luteolin in selected marketed ayurvedic formulations of'Dashmula'and in ethyl acetate extract of Premna integrifolia L. J Anal Bioanal Tech. 2017;8(343):2.

7. Romanová $D$, Grančai $D$, Jóžová $B$, Božek $P$, Vachálková A. Determination of apigenin in rat plasma by high-performance liquid chromatography. J Chromatogr A. 2000;870(1-2):463-7. doi: 10.1016/s0021-9673(99)00939-5, PMID 10722103.

8. Miguel FG, Cavalheiro AH, Spinola NF, Ribeiro DL, Barcelos GR, Antunes LM, Hori JI, Marquele-Oliveira F, Rocha BA, Berretta AA. Validation of a RP-HPLC-DAD method for chamomile (Matricaria recutita) preparations and assessment of the marker, apigenin-7-glucoside, safety and anti-inflammatory effect. Evid Based Complement Alternat Med. 2015 Oct;2015:828437. doi: 10.1155/2015/828437, PMID 26421053.

9. Guzelmeric E, Vovk I, Yesilada E. Development and validation of an HPTLC method for apigenin 7-O-glucoside in chamomile flowers and its application for fingerprint discrimination of chamomile-like materials. J Pharm Biomed Anal. 2015 Mar 25;107:108-18. doi: 10.1016/j.jpba.2014.12.021, PMID 25575175.

10. Wang $Y, X u$ Z, Huang $Y$, Wen $X$, Wu $Y$, Zhao $Y$, Ni Y. Extraction, purification, and hydrolysis behavior of apigenin-7-O-glucoside from Chrysanthemum morifolium tea. Molecules. 2018 Nov;23(11):2933. doi: 10.3390/ molecules23112933, PMID 30424020.

11. Romanova D, Vachalkova A. UV spectrometric and DC polarographic studies on apigenin and luteolin. Arch Pharm Res. 1999 Apr;22(2):173-8. doi: 10.1007/BF02976542, PMID 10230508.

12. Arun $\mathrm{P}$, Amol T, Darshan T. Preparation, development and validation of UV spectrophotometric method for the estimation of apigenin in apigeninhydrogenated soy phosphatidylcholine (HSPC) complex. Int J Pharm Pharm Sci. 2015;7(3):228-31.

13. $\mathrm{ICH}$ guidance, validation of analytical method: definition and terminology International Conference on Harmonization. Vol. Q2A. Geneva.

14. ICH guidance, validation of analytical procedures: methodology. International Conference on Harmonization. Vol. Q2B. Geneva.

\section{SUMMARY}

The present study delivers a reference line data and analytical methods to contribution in the evaluation of apigenin, Plant flavonoid having capable chemo preventive activity counter to various cancers. Apigenin has low solubility which soluble in DMSO. Many studies on HPLC, HPTLC analysis for apigenin have been reported but till date UV Spectrophotometric method for apigenin isolated compound has not been reported. Here in this study the UV Spectra of apigenin was recorded by taking methanol as solvent, which sturdily absorbed gave two absorption spectra at a wavelength of 267 and $336 \mathrm{~nm}$ herein we selected $267 \mathrm{~nm}$ as it produced a sharp peak compared to $336 \mathrm{~nm}$. Upright linearity was found with in concentration range of $2-10 \mu \mathrm{g} / \mathrm{mL}$ with correlation coefficient $\left(\mathrm{r}^{2}\right)$ at 0.999. The data of precision study (interday and intraday) represent a good reproducibility with the RSD lower than $2.0 \%$ which shows that the method is precise. The use of costly analytical methods like HPLC, HPTLC limit the realizations of in situ studies because of their high cost, their limited portability, and even extend the time duration of the study. Henceforth the simple UV method was developed for the estimation of Apigenin in various extracts and in the marketed formulation and this developed method is validated according to the ICH guidelines. 


\section{PICTORIAL ABSTRACT}

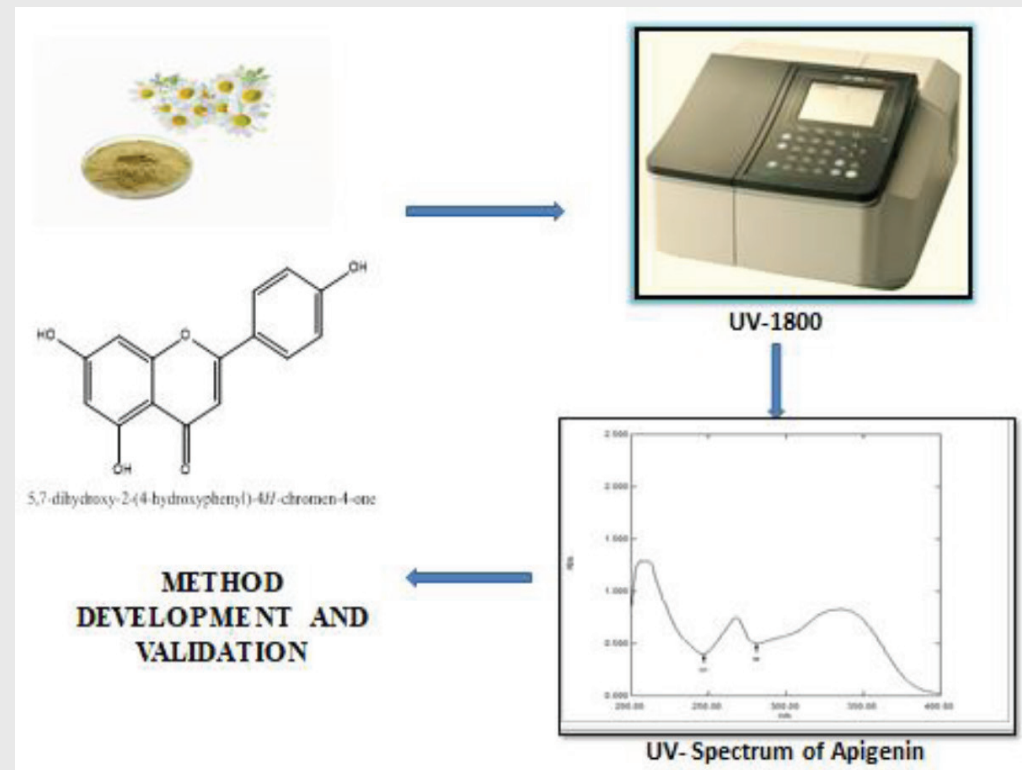

About Authors

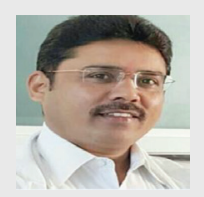

Prof. Sunil S. Jalalpure, presently working as a Professor, Department of Pharmacognosy, College of Pharmacy, KLE University, Belgaum. He completed his B.Pharm. from Karnataka University, Dharwad and obtained his M.Pharm. and Ph.D. degrees from Rajiv Gandhi University of Health Sciences, Bangalore, Karnataka. He has undergone research training at Rhodes University, Grahamstown, South Africa, on analytical instruments used in the standardization and quality assurance of pharmaceuticals.

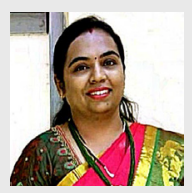

Mrs. Priya P Shetti is a PhD Scholar at KLE College of Pharmacy, Belagavi, KLE Academy of Higher Education and Research Belagavi. Her current research interest is in development and evaluation of nanoformulation in treatment of Breast Cancer, cell culture based experiment, analytical method development, Nano particulate drug delivery system.

Cite this article: Shetti P, Jalalpure SS. Optimization of a Validated UV-Spectrophotometric Methodology for Assessment of Apigenin in Bulk Powder. Indian J of Pharmaceutical Education and Research. 2022;56(1):281-6. 